\title{
Synthesis and evaluation of some novel precursors of oxazolidinone analogues of chloroquinoline for their antimicrobial and cytotoxic potential
}

\author{
KAVITA DEVI ${ }^{\mathrm{a}}$, YUMNA ASMAT ${ }^{\mathrm{a}}$, MEENAKSHI AGRAWAL $^{\mathrm{a}}$, SWAPNIL SHARMA $^{\mathrm{b}, *}$ and \\ JAYA DWIVEDI ${ }^{\mathrm{a}}$ \\ ${ }^{a}$ Department of Chemistry, ${ }^{b}$ Department of Pharmacy, Banasthali University, Banasthali 304 022, India \\ e-mail: swapnilsharma1978@gmail.com
}

MS received 12 May 2012; revised 22 March 2013; accepted 4 July 2013

\begin{abstract}
Some 3-(3-(7-chloroquinolin-4-ylamino)propyl-2-imino-5-(4-chloro/nitro/methoxy benzylidene) oxazolidin-4-one 4(a-c) and 4-(3-(7-chloroquinolin-4-ylamino) propyl)-2(4-chloro/nitro/methoxy benzylidene)-1,6-diox-4,9 diazaspiro[4,4]nonane-3,8-dione 5(a-c) derivatives were synthesized using appropriate synthetic route. The newly prepared compounds 5a-c demonstrated inhibitory effects on the growth of a MCF7 (hormone-dependant breast carcinoma cell line), HT29 (colon carcinoma cell line on leukemia). The MCF7 cell line was found to be very susceptible towards compound $\mathbf{5 a}$ with $\mathrm{IC}_{50}$ values of $16 \mu \mathrm{g} / \mathrm{ml}$. Similarly, the HT29 cell line was found to be moderately susceptible towards compounds $\mathbf{5 a}$ and $\mathbf{5 c}$ with IC 50 values of 32 and $49 \mu \mathrm{g} / \mathrm{ml}$, respectively.
\end{abstract}

Keywords. Synthesis; 4-7-dichloroquinoline; 1-3-diaminopropane; oxazolidinone; antimicrobial activity and cytotoxicity study.

\section{Introduction}

Heterocyclic chemistry has great importance to the medicinal chemists because large numbers of heterocyclic compounds are being used as therapeutic agents and these compounds are also essential for the human life as oxazolidinones. Oxazolidinones are a novel class of synthetic antimicrobial agents ${ }^{1,2}$ which have now entered phase III clinical trials. The most important results of extensive studies (synthesis, spectral, structural characterization and applications in various biological systems) of oxazolidinone derivatives are reviewed. A large number of oxazolidinone are known but still there is a need to develop new derivatives in different fields for biomedical applications and it has recently drawn the attention of numerous research groups, making this area constantly evolve. The most promising feature of oxazolidinone is their oral activity against multidrug-resistant ${ }^{3}$ which has created tremendous therapeutic problems in recent years. In addition, in vitro development of resistance has so far remained below detectable levels. Different from many antibacterial agents used in the treatment of human infections, ${ }^{4}$ oxazolidinones do not block bacterial protein synthesis at the level of polypeptide chain

*For correspondence elongation but rather seem to interfere with initiation of translation. ${ }^{5}$ Both binding of formylmethioninetransfer RNA to initiation complexes as well as release of formylmethionine puromycin from initiation complexes have been reported to be targets for oxazolidinones. ${ }^{6,7}$ The major binding sites of oxazolidinones are the large (50S) ribosomal subunits. ${ }^{8}$ Oxazolidinones were first described by Eleuthère Irénée du Pont de Nemours and Co. in 1987 as a novel class of synthetic antimicrobial agents. ${ }^{9}$ The first representative, DuP 721 (figure 1) showed promising activity against multidrugresistant Gram-positive bacteria ${ }^{10}$ a low occurrence of resistance development, ${ }^{11-13}$ anticancer, ${ }^{14-16}$ antifungal, ${ }^{17}$ anticonvulsant, ${ }^{18}$ antiinflammatory, ${ }^{19,20}$ antituberculosis ${ }^{21,22}$ anti-HIV ${ }^{23-25}$ and antidiabetic. ${ }^{26}$ The analogues of oxazolidinone, eperezolid (PNU-100592) and linezolid (PNU-100766) (figure 1) were developed by Pharmacia and Upjohn. Linezolid has now entered phase III clinical testing and is used for the treatment of infections caused by both susceptible and antibiotic-resistant Gram-positive bacteria. (Azolylphenyl)oxazolidinones, in which the morpholine ring of linezolid is replaced with five-memberedring heterocyclics containing nitrogen and sulphur atoms are new developments with promisingly low minimal inhibitory concentrations towards susceptible bacteria. $^{27}$ 


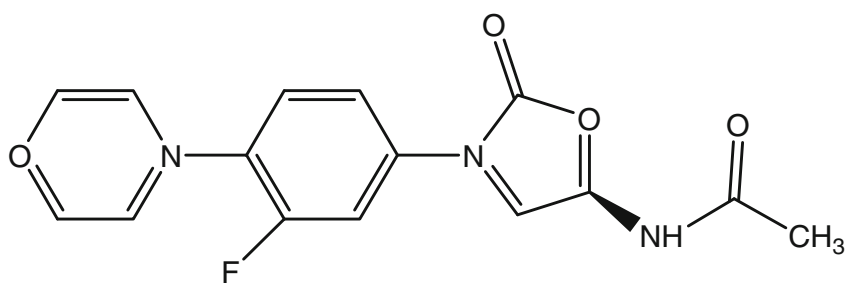

Figure 1. Linezolid.

Quinoline derivatives occur abundantly in natural products as well as in synthetic compounds of biological interest. ${ }^{28}$ They are known to exhibit antiallergenic properties, ${ }^{29}$ antifungal activity, ${ }^{30}$ hypocholesterolemic, ${ }^{31}$ hypovolemia, ${ }^{32}$ antibacterial ${ }^{33}$ and antiviral activity. ${ }^{34}$ Thienoquinoline and benzothienoquinolines have been demonstrated to exhibit antitumour and antimicrobial activities. ${ }^{35}$

On the basis we describe the synthesis of novel oxazolidinone derivatives with a view of verify this assumption that its incorporation of quinoline could really produce an additive affect on the biological properties of the parent molecule. The present study focuses on synthesis (scheme 1), evaluation of antimicrobial and in vitro cytotoxicity properties of N1-(7-chloroquinoline4-yl)propane-1,3-diamine (1), 3-(3-(7-chloroquinoline4-yl-amino) propyl)-2-imino-oxazolidin-4-one (3)-(3(7-chloroquinolin-4-ylamino)propyl-2-imino-5-(4-chlorobenzylidene)oxazolidin-4-one (4a) and 4-(3-(7-chloroquinolin-4-ylamino)propyl)-2(4-nitrobenzylidene)-1, 6-diox-4,9-diazaspiro[4,4]nonane-3,8-dione (5b).

\section{Experimental}

The entire chemicals were purchased from Aldrich Chemical Company (USA) and were used after purification by distillation. The reactions were monitored by pre-coated aluminium silica gel 60F 254 thin-layer plates procured from Merck (Germany). All melting points were measured by capillary apparatus and are uncorrected. All the compounds were routinely checked by IR, ${ }^{1} \mathrm{H}-\mathrm{NMR}$ and mass spectrometries. IR spectra were recorded in $\mathrm{KBr}$ on a Perkin-Elmer model 8201 FTIR spectrophotometer. ${ }^{1} \mathrm{H}-\mathrm{NMR}$ spectra were recorded at ambient temperature using a Brucker spectroscopin DPX-300 MHz spectrophotometer in DMSO. The following abbreviations were used to indicate the peak multiplicity s-singlet, d-doublet, t-triplet, and mmultiplet. FAB mass spectra were recorded on a JEOL SX102 mass spectrometer using Argon/Xenon $(6 \mathrm{kV}$, $10 \mathrm{mB}$ ) gas. Column chromatography was performed on silica gel (Merck). Anhydrous sodium sulphate was used as a drying agent for the organic phase.

\subsection{Preparation of $N$-(7-chloroquinoline-4-yl) propane-1, 3-diamine (1)}

A mixture of 4-7-dichloroquinoline (1.96 gm, $15 \mathrm{mmol})$ and 1-3-diaminopropane $(1.68 \mathrm{ml}, 20 \mathrm{mmol})$ in ethanol was refluxed with stirring for $12 \mathrm{~h}$. It was cooled and distilled the solvent. Solid product was dissolved in DCM $(80 \mathrm{ml})$, washed with $5 \%$ of sodium

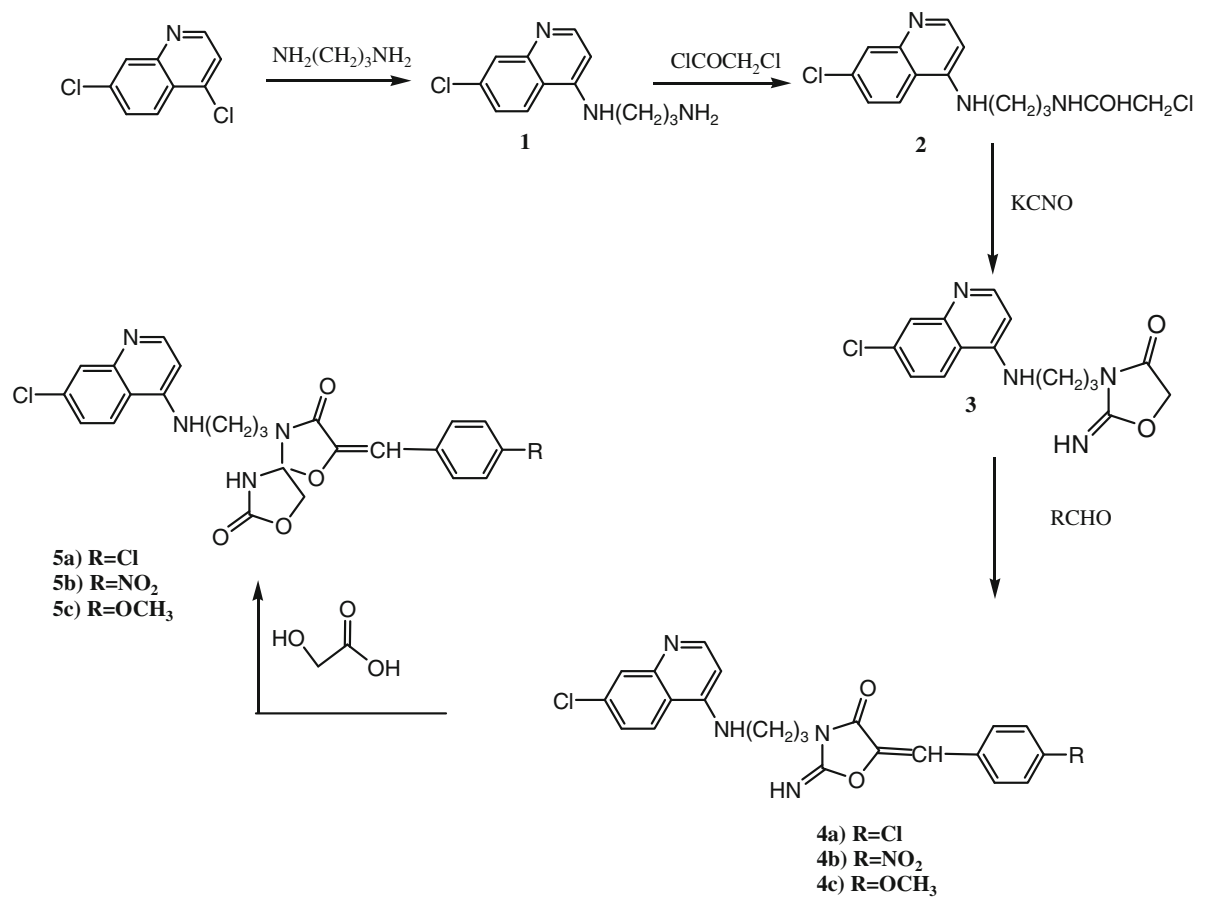

Scheme 1. Schematic presentation of synthesis of some spirooxazolidinones from 4-7-dichloroquinoline. 
bicarbonate and brine solution. The organic layer was filtered. The solid product was purified over the column of silica gel and eluted with ethanol as an eluent to give compound 1 (yield $80 \%$ ), m.p. $90-92^{\circ} \mathrm{C}$. IR (KBr) cm $\mathrm{cm}^{-1}$ 3457, 3225 [NH str.], 2928[C-H str. Ar. H], 1200 [C-N str.], 1559 [NH str.], 786 [C-Cl str.], 1485 [C-H bend. $\left.\mathrm{CH}_{2}\right] .{ }^{1} \mathrm{H}-\mathrm{NMR}\left(\mathrm{CDCl}_{3}\right) \delta 8.64(\mathrm{~d}, 1 \mathrm{H}, \mathrm{CH})$, 8.00(s, 1H,CH), $7.61(\mathrm{~d}, 1 \mathrm{H}, \mathrm{CH}), 7.43(\mathrm{~d}, 1 \mathrm{H}, \mathrm{CH})$, $6.49(\mathrm{~d}, 1 \mathrm{H}, \mathrm{CH}), 4.12(\mathrm{~s}, 1 \mathrm{H}, \mathrm{NH}) 2.0(\mathrm{~s}, 1 \mathrm{H}, \mathrm{NH}), 1.7$ (m, 6H,CH). MS: [m/z] $235.71(\mathrm{M}+1)$. Anal. Calcd./ found for $\mathrm{C}_{12} \mathrm{H}_{14} \mathrm{ClN}_{3}$ : C, 61.15/61.04; $\mathrm{H}, 5.99 / 5.92$; $\mathrm{Cl}, 15.04 / 15.08 ; \mathrm{N}, 17.83 / 17.76$.

\subsection{Preparation of 2-chloro- $N$-(3-(-7-chloroquinoline-} 4-ylamino) propyl) acetamide (2)

Compound N-(7-chloroquinoline-4-yl) propane-1, 3-diamine (1) $(2.35 \mathrm{~g}, 10 \mathrm{mmol})$, triethyl amine $(1 \mathrm{ml}, 1.01 \mathrm{mmol})$ and chloroacetyl chloride $(0.75 \mathrm{ml}$, $10 \mathrm{mmol})$ were dissolved in dry ethanol $(25 \mathrm{ml})$. The mixture was stirred for $30 \mathrm{~min}$ on ice bath then refluxed with stirring for $4-6 \mathrm{~h}$. Reaction mixture was cooled and solvent was evaporated. Now, solid product was dissolved in DCM and water. Organic layer was extracted. Solvent was distilled and obtained solid was purified over the column of silica gel and eluted with ethanol to give compound 2 (yield $72 \%$ ), m.p. $80-82^{\circ}$ C. IR (KBr) cm ${ }^{-1} 1517,1490[\mathrm{NH}$ str.], 3200, 2983[C-H str. $\mathrm{CH}_{2}$ ], 798 [C-Cl str.], 2983 [C-H bend $\mathrm{CH}_{2}$ ], 1217 [C-N str.], 1700 [CO str.]. ${ }^{1} \mathrm{H}-\mathrm{NMR}$ $\left(\mathrm{CDCl}_{3}\right) \quad \delta \quad 8.74[\mathrm{~s}, 1 \mathrm{H}, \mathrm{NH}], \quad 8.29[\mathrm{~s}, 1 \mathrm{H}, \mathrm{Ar} . \mathrm{CH}], \quad 8.06$ [d,1H,Ar.CH], 7.63[d,1H,Ar.CH], 7.41[d,1H,Ar.CH], $6.68[\mathrm{~d}, 1 \mathrm{H}, \mathrm{Ar} . \mathrm{CH}], \quad 4.23[\mathrm{~s}, 1 \mathrm{H}, \mathrm{NH}], \quad 3.82\left[\mathrm{t}, 2 \mathrm{H}, \mathrm{CH}_{2}\right]$, 1.24-1.75[m, 6H, $\left.\mathrm{CH}_{2}\right]$. MS: [m/z] $312.19(\mathrm{M}+1)$; Anal. Calcd. /found for $\mathrm{C}_{14} \mathrm{H}_{15} \mathrm{Cl}_{2} \mathrm{~N}_{3} \mathrm{O}: \mathrm{C}, 53.86 / 53.81$; $\mathrm{H}, 4.84 / 4.76 ; \mathrm{Cl}, 22.71 / 22.60 ; \mathrm{N}, 13.46 / 13.32 ; \mathrm{O}$, $5.12 / 5.5$

\subsection{Preparation of 3-(3-(7-chloroquinoline-4-yl- amino) propyl)-2-imino-oxazolidin-4-one (3)}

A mixture of 2-chloro-N-(3-(-7-chloroquinoline-4-ylamino) propyl) acetamide (2) $(1.66 \mathrm{~g}, 5 \mathrm{mmol})$ and potassium cyanate $(0.58 \mathrm{mg}, 7 \mathrm{mmol})$ was dissolved in dry acetone $(10 \mathrm{ml})$. The reaction mixture was refluxed on steam bath for $4-6 \mathrm{~h}$. The solvent was distilled to yield a solid, which was purified through a column of silica gel and eluted with ethanol to give compound 3 (yield $65 \%$ ), m.p. $78-80^{\circ} \mathrm{C}$. IR $(\mathrm{KBr}) \mathrm{cm}^{-1} 1578$ [NH str.], 3124, 3345 [C-H str. Ar. H], 1678 [NH str.], 1308 [C-Cl str.], 2867 [C$\mathrm{H}$ str. $\mathrm{CH}_{2}$ ], 1308 [C-N str.], $1704[\mathrm{C}=\mathrm{O}] .{ }^{1} \mathrm{H}-\mathrm{NMR}$
$\left(\mathrm{CDCl}_{3}\right) \quad \delta \quad 11.7 \quad[\mathrm{~s}, 1 \mathrm{H}, \mathrm{NH}], 8.65 \quad[\mathrm{~d}, 1 \mathrm{H}, \mathrm{Ar} . \mathrm{CH}], 8.56$ [s,1H,NH],8.10 [d,1H,Ar.CH],7.79 [d,1H,Ar.CH],6.69 [d,1H,Ar.CH],4.14 [s,2H,CH],3.97 [t,2H, $\left.\mathrm{CH}_{2}\right], 1.39-$ $1.32\left[\mathrm{~m}, 4 \mathrm{H}, \mathrm{CH}_{2}\right]$. MS: [m/z] $318(\mathrm{M}+1)$. Anal. Calcd./found for $\mathrm{C}_{15} \mathrm{H}_{15} \mathrm{ClN}_{4} \mathrm{O}_{2}$ : C, 56.52/56.42; H, 4.74/4.70; Cl, 11.12/11.02; N, 17.78/17.72; O, 10.04/9.

\subsection{Preparation of 3-(3-(7-chloroquinolin-4-ylamino)} propyl-2-imino-5-(4-chloro benzylidene)

oxazolidin-4-one $(\mathbf{4 a})$

A mixture of compound 3-(3-(7-chloroquinoline-4-ylamino) propyl)-2-imino-oxazolidin-4-one (3) (0.30 g, $0.99 \mathrm{mmol})$ and sodium acetate $(0.10 \mathrm{~g}, 0.001 \mathrm{mmol})$ was mixed with p-chlorobenzaldehyde $(0.127 \mathrm{~g}$, $1.2 \mathrm{mmol})$ in dry benzene $(20 \mathrm{ml})$. The reaction mixture was refluxed on water bath for $8 \mathrm{~h}$, cooled at room temperature, filtered and the solid was purified by column chromatography to give compound 4a (yield 68\%), m.p. $76-78^{\circ} \mathrm{C}$ IR (KBr) cm ${ }^{-1} 3187$, 2856[CHstr.Ar.H], $1705[\mathrm{C}=\mathrm{O}], \quad 1674 \quad[\mathrm{C}=\mathrm{C}$ str.], 1567 [NH str.(Amine)],1456[NH str.(Imine)], 1389 [C-H bend. $\left.\mathrm{CH}_{2}\right], 1277[\mathrm{C}-\mathrm{N}$ str.] and 767,678[C-Cl str.]. ${ }^{1} \mathrm{H}-\mathrm{NMR}\left(\mathrm{CDCl}_{3}\right) \delta 9.26[\mathrm{~s}, 1 \mathrm{H},(\mathrm{NH})], .62[\mathrm{dd}, 2 \mathrm{H}$, ArH],8.21[s, 1H, ArH],7.51[d,2H, ArH], 7.34[dd,2H, $\mathrm{ArH}], 7.24[\mathrm{~s}, 2 \mathrm{H}, \mathrm{C}=\mathrm{H}], 7.22[\mathrm{dd}, 1 \mathrm{H}, \mathrm{ArH}], 6.29[\mathrm{~d}, 1 \mathrm{H}$, $\mathrm{ArH}], 4.36[\mathrm{~s}, 1 \mathrm{H},(\mathrm{NH})]$ and $1.83-2.76\left[\mathrm{~m}, 6 \mathrm{H}, \mathrm{CH}_{2}\right]$. MS: [m/z] $440(\mathrm{M}+1)$. Anal. Calcd./found for $\mathrm{C}_{22} \mathrm{H}_{18} \mathrm{Cl}_{2} \mathrm{~N}_{4} \mathrm{O}_{2}$ : C, 59.88/59.82; $\mathrm{H}, 4.11 / 4.08 ; \mathrm{Cl}$, 16.07/16.01; N, 12.07/12.02, O; 7.25/7.29.

\subsection{Preparation of 3-(3-(7-chloroquinolin-4-ylamino) propyl-2-imino-5-(4-chloro benzylidene) \\ oxazolidin-4-one $(\mathbf{4 b})$}

A mixture of compound 3-(3-(7-chloroquinoline-4-ylamino) propyl)-2-imino-oxazolidin-4-one (3) (0.37 g, $0.50 \mathrm{mmol})$ and sodium acetate $(0.10 \mathrm{~g}, 0.001 \mathrm{mmol})$ was mixed with p-nitrobenzaldehyde $(0.134 \mathrm{~g}$, $1.2 \mathrm{mmol})$ in dry benzene $(20 \mathrm{ml})$. The reaction mixture was refluxed on water bath for $8 \mathrm{~h}$, cooled at room temperature, filtered and the solid was purified by column chromatography to give compound $\mathbf{4 b}(1.32 \mathrm{~g}$, yield 56\%), m.p. $115-117^{\circ} \mathrm{C}$ IR (KBr) cm $\mathrm{cm}^{-1} 3196$, 2945[CHstr.Ar.H], 1710[C=O], 1586 [C=C str.],1569 [NH str.(Imine)], 1508 [NH str.(Amine)],1500[N$\mathrm{O}$ str.],1458 [C-H bend. $\left.\mathrm{CH}_{2}\right], 1356[\mathrm{C}-\mathrm{N}$ str.] and $681\left[\mathrm{C}-\mathrm{Cl}\right.$ str.]. ${ }^{1} \mathrm{H}-\mathrm{NMR}\left(\mathrm{CDCl}_{3}\right) \delta 9.41[\mathrm{~s}, 1 \mathrm{H},(\mathrm{NH})]$, 8.45[dd,2H, ArH], 8.14[dd,1H,ArH], 8.15[s, $1 \mathrm{H}$, $\mathrm{ArH}], 7.66[\mathrm{~d}, 1 \mathrm{H}, \operatorname{ArH}], 7.56[\mathrm{dd}, 2 \mathrm{H}, \mathrm{ArH}], 7.43[\mathrm{~s}, 2 \mathrm{H}$, $\mathrm{C}=\mathrm{H}], \quad 6.39[\mathrm{~d}, 1 \mathrm{H}, \quad \operatorname{ArH}], \quad 4.21[\mathrm{~s}, 1 \mathrm{H},(\mathrm{NH})], 1.78-$ 2.96[m,6H $\left.\left(\mathrm{CH}_{2}\right)\right]$ MS: [m/z] $451(\mathrm{M}+1)$ Anal. 
Calcd./found for $\mathrm{C}_{22} \mathrm{H}_{18} \mathrm{ClN}_{5} \mathrm{O}_{4}$ : C, 58.48/58.49; $\mathrm{H}, 4.02 / 4.06 ; \mathrm{Cl}, 7.85 / 7.92 ; \mathrm{N}, 15.50 / 15.23$ ， O; 14.16/14.10.

\subsection{Preparation of 3-(3-(7-chloroquinolin-4-ylamino)} propyl-2-imino-5-(4-methoxy benzylidene) oxazolidin-4-one $(\mathbf{4 c})$

Compound 3-(3-(7-chloroquinoline-4-ylamino)propyl)2-imino-oxazolidin-4-one (3) of $(0.30 \mathrm{~g}, 0.13 \mathrm{mmol})$ and zinc chloride $(0.50 \mathrm{mg}, 0.003 \mathrm{mmol})$ was mixed with p-methoxybenzaldehyde $(0.127 \mathrm{~g}, 0.017 \mathrm{mmol}))$ in glacial acetic acid $(20 \mathrm{ml})$. The reaction mixture was refluxed on sand bath at $120^{\circ} \mathrm{C}$ for $8 \mathrm{~h}$. Cooled, neutralized with $\mathrm{NaHCO}_{3}$. Obtained white solid was poured in the cold water and filtered. The obtained solid was purified by column chromatography to give 4c. IR (KBr) $\mathrm{cm}^{-1}$ 3278,2876[CHstr.Ar.H],1705[C=O],1678 [C=C str.],1578 [NH str.(Imine)], 1545 [NH str.(Amine)], 1487 [C-H bend. $\mathrm{CH}_{2}$ ], 1329[C-O(Eater)], 1142[C$\mathrm{N}$ str.] and $772\left[\mathrm{C}-\mathrm{Cl}\right.$ str.]. ${ }^{1} \mathrm{H}-\mathrm{NMR}\left(\mathrm{CDCl}_{3}\right) \delta$ $8.41[\mathrm{~s}, 1 \mathrm{H},(\mathrm{NH})], 8.62[\mathrm{~d}, 1 \mathrm{H}, \mathrm{ArH}], 8.12[\mathrm{~s}, 1 \mathrm{H}, \mathrm{ArH}]$, $7.69[\mathrm{~d}, 2 \mathrm{H}, \mathrm{ArH}], 7.43[\mathrm{~s}, 1 \mathrm{H},=\mathrm{CH}], 7.19[\mathrm{dd}, 1 \mathrm{H}, \mathrm{ArH}]$, 6.72[dd,2H, ArH], 6.49[d,1H, ArH], 4.11[s,1H, $(\mathrm{NH})]$, $3.73\left[\mathrm{~s}, 3 \mathrm{H}, \mathrm{CH}_{3}\right], 1.88-2.15\left[\mathrm{~m}, 6 \mathrm{H}\left(\mathrm{CH}_{2}\right)\right] . \mathrm{MS}:[\mathrm{m} / \mathrm{z}]$ $436(\mathrm{M}+1)$ Anal. Calcd./found for $\mathrm{C}_{23} \mathrm{H}_{21} \mathrm{ClN}_{4} \mathrm{O}_{3}$. $\mathrm{C}, \quad 64.59 / 64.72 ; \mathrm{H}, \quad 7.23 / 7.45 ; \mathrm{Cl}, \quad 7.06 / 7.12$; $\mathrm{N}, 13.25 / 13.32 ; \mathrm{O}, 11.01 / 11.08$.

\subsection{Preparation of 4-(3-(7-chloroquinolin-4-ylamino)} propyl)-2(4-chlorobenzylidene)-1, 6-diox-4, 9-diazaspiro[4,4]nonane-3,8-dione 5(a)

Compound 3-(3-(7-chloroquinolin-4-ylamino)propyl2-imino-5-(4-chloro benzylidene)oxazolidin-4-one (4a) $(0.20 \mathrm{~g}, 0.45 \mathrm{mmol})$ was mixed with glycolic acid $(3.37 \mathrm{~g}, 0.023 \mathrm{mmol})$ and dissolved in dry benzene $(20 \mathrm{ml})$. The reaction mixture was refluxed on water bath for $6-7 \mathrm{~h}$, cooled at room temperature, washed with $\mathrm{NaHCO}_{3}$ solution and filtered. The organic layer was dried over anhydrous $\mathrm{Na}_{2} \mathrm{SO}_{4}$, concentrated and purified by column chromatography. The product was recrystallized with ethanol to give compound 5a (yield 54\%), m.p. $95-97^{\circ} \mathrm{C}$ IR (KBr) cm ${ }^{-1} 1500$ [NH str.], 3272, 3049 [C-H str. Ar-H], 763, 680 [C-Cl str.], 1299 [C-N str.], $1454\left[\mathrm{C}-\mathrm{H}\right.$ bend. $\mathrm{CH}_{2}$ ], $1481\left[\mathrm{C}=\mathrm{C}\right.$ str.],1735[C=O]. ${ }^{1} \mathrm{H}-\mathrm{NMR} \quad\left(\mathrm{CDCl}_{3}\right) \delta$ 11.5[s, 1H, NH] , 4.1[s,1H, NH], 8.6[d,3H,Ar.CH], 6.97.1[d, 2H, Ar.CH],7.8[m,4H,Ar.CH],3.4[s,2H, $\left.\mathrm{CH}_{2}\right]$, 1.5-2.0[m,6H $\left.\left(\mathrm{CH}_{2}\right)\right] .{ }^{13} \mathrm{C}-\mathrm{NMR}\left(\mathrm{CDCl}_{3}\right) \delta 151.9 \mathrm{C}_{1}$, $113.0 \mathrm{C}_{2}, 123.0 \mathrm{C}_{4}, 126.6 \mathrm{C}_{5}, 134.5 \mathrm{C}_{6}, 160.8 \mathrm{C}=\mathrm{O}$, $126.6 \mathrm{C}_{7}, 38.9 \mathrm{C}_{10}, 39.5 \mathrm{C}_{11}, 77.5 \mathrm{C}_{12}, 38.7 \mathrm{C}_{13}, 138.7$
$\mathrm{C}_{16}, 123.2 \mathrm{C}_{18}, 127.8 \mathrm{C}_{23}$, MS: [m/z] 499(M+1). Anal. Calcd./found for for $\mathrm{C}_{24} \mathrm{H}_{21} \mathrm{Cl}_{2} \mathrm{~N}_{4} \mathrm{O}_{4}$ : C, 57.73/57.67; $\mathrm{H}, 4.04 / 4.00 ; \mathrm{Cl}, 14.20 / 14.16 ; \mathrm{N}, 11.22 / 11.20$, O; $12.82 / 12.70$.

2.8 Preparation of 4-(3-(7-chloroquinolin-4-ylamino) propyl)-2(4-nitrobenzylidene)-1, 6-diox-4,

9-diazaspiro[4,4]nonane-3,8-dione 5(b)

Compound 3-(3-(7-chloroquinolin-4-ylamino)propyl2-imino-5-(4-nitro benzylidene)oxazolidin-4-one (4b) $(3.37 \mathrm{~g}, 0.12 \mathrm{mmol})$ was mixed with glycolic acid $(3.37 \mathrm{~g}, 0.023 \mathrm{mmol})$ and dissolved in dry benzene $(20 \mathrm{ml})$. The reaction mixture was refluxed on water bath for $6-7 \mathrm{~h}$, cooled at room temperature, washed with $\mathrm{NaHCO}_{3}$ solution and filtered. The organic layer was dried over anhydrous $\mathrm{Na}_{2} \mathrm{SO}_{4}$, concentrated and purified by column chromatography. The product was recrystallized with ethanol to give compound $\mathbf{5 b}$ (yield

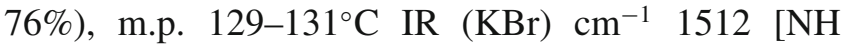
str.], 3272, 2998 [C-H str. Ar-H], 762, [C-Cl str.], 1290 [C-N str.], $1454\left[\mathrm{C}-\mathrm{H}\right.$ bend. $\left.\mathrm{CH}_{2}\right], 1600[\mathrm{C}=\mathrm{C}$ str.], $1735[\mathrm{C}=\mathrm{O}], 1500\left[\mathrm{~N}-\mathrm{O}\right.$ str.]. ${ }^{1} \mathrm{H}-\mathrm{NMR}\left(\mathrm{CDCl}_{3}\right) \delta$ 8.2[d,3H,Ar.CH], 7.7[d,2H, Ar.CH],7.6[m,4H,Ar.CH], $4.1[\mathrm{~s}, 1 \mathrm{H}, \mathrm{NH}], 11.5\left[\mathrm{~s}, 1 \mathrm{H}, \mathrm{NH}, 3.9\left[\mathrm{~s}, 2 \mathrm{H},\left(\mathrm{CH}_{2}\right)\right], 1.2-\right.$ $2.0\left[\mathrm{~m}, 6 \mathrm{H}\left(\mathrm{CH}_{2}\right)\right] .{ }^{13} \mathrm{C}-\mathrm{NMR}\left(\mathrm{CDCl}_{3}\right) \delta 152.9 \mathrm{C}_{1}, 104.4$ $\mathrm{C}_{2}, 120.5 \mathrm{C}_{4}, 126.8 \mathrm{C}_{5}, 127.8 \mathrm{C}_{6}, 170.7 \mathrm{C}=\mathrm{O}, 45.6$ $\mathrm{C}_{10}, 40.9 \mathrm{C}_{11}, 78.8 \mathrm{C}_{12}, 39.9 \mathrm{C}_{13}, 149.4 \mathrm{C}_{17}, 127.5$ $\mathrm{C}_{23}$. MS: [m/z] $542(\mathrm{M}+1)$ Anal. Calcd./found for $\mathrm{C}_{24} \mathrm{H}_{21} \mathrm{ClN}_{5} \mathrm{O}_{6}$ : C, 58.48/58.49; $\mathrm{H}, 4.02 / 4.06 ; \mathrm{Cl}$, 7.85/7.92; N, 15.50/15.23, O; 14.16/14.10.

\subsection{Preparation of 4-(3-(7-chloroquinolin-4-ylamino)} propyl)-2(4-methoxy benzylidene)-1, 6-diox-4, 9-diazaspiro[4,4]nonane-3,8-dione 5(c)

A mixture of compound 3-(3-(7-chloroquinolin-4-ylamino)propyl-2-imino-5-(4-methoxy benzylidene) oxazolidin-4-one (4c) $(0.30 \mathrm{~g}, 0.12 \mathrm{mmol})$, zinc chloride $(0.50 \mathrm{mg}, 0.001 \mathrm{mmol})$ and glycolic acid $(3.37 \mathrm{~g}$, $0.25 \mathrm{mmol})$ was dissolved in glacial acetic acid $(20 \mathrm{ml})$. The reaction mixture was refluxed on sand bath for 6-7 h. The temperature of the reaction mixture was raised up to $120^{\circ} \mathrm{C}$ and maintained. The completion of the reaction checked by TLC. The reaction mixture was cooled at room temperature, neutralized with ammonium hydroxide and filtered. The precipitate was poured in cold water and filtered. The resultant product was purified by column chromatography using silica absorbent system (8:2 (benzene: methanol)). The product was recrystallized with ethanol to give $\mathbf{5 c}$. 
IR (KBr) $\mathrm{cm}^{-1} 3263[\mathrm{NH}$ str.(Amine)], 3043,2987[C$\mathrm{H} \quad$ str. $], \quad 1705[\mathrm{C}=\mathrm{O}$ (str.) $], 1658[\mathrm{C}=\mathrm{CH}], 1500[\mathrm{NH}$ (Amine)], 1458 [C-H bend $\left.\mathrm{CH}_{2}\right], 1278[\mathrm{C}-\mathrm{N}$ str.], $1311[\mathrm{C}-\mathrm{O}$ (str.) $]$ and $750\left[\mathrm{C}-\mathrm{Cl}\right.$ str.(Aro)]. ${ }^{1} \mathrm{H}-\mathrm{NMR}$ $\left(\mathrm{CDCl}_{3}\right) \delta 11.5[\mathrm{~s}, 1 \mathrm{H}, \mathrm{NH}], 8.5[\mathrm{~s}, 1 \mathrm{H}, \mathrm{Ar} . \mathrm{H}], 8.0[\mathrm{dd}, 2 \mathrm{H}$, $\operatorname{ArH}], 7.7[\mathrm{~d}, 1 \mathrm{H}, \quad \operatorname{ArH}], \quad 7.5[\mathrm{~d}, 1 \mathrm{H}, \quad \operatorname{ArH}], \quad 7.3[\mathrm{~d}, 1 \mathrm{H}$, $\mathrm{ArH}], 7.2[\mathrm{dd}, 2 \mathrm{H}, \mathrm{ArH}], 7.0[\mathrm{~d}, 1 \mathrm{H}, \mathrm{ArH}], 6.6[\mathrm{~s}, 2 \mathrm{H}$, $(\mathrm{C}=\mathrm{H})], 4.1[\mathrm{~s}, 1 \mathrm{H}, \mathrm{NH}], 3.0\left[\mathrm{~s}, 2 \mathrm{H},\left(\mathrm{Ar} . \mathrm{CH}_{2}\right)\right], 2.4[\mathrm{~s}, 3 \mathrm{H}$, $\left.\left(\mathrm{CH}_{3}\right)\right]$ and $1.8-1.0\left[\mathrm{~m}, 6 \mathrm{H}\left(\mathrm{CH}_{2}\right)\right] \cdot{ }^{13} \mathrm{C}-\mathrm{NMR}\left(\mathrm{CDCl}_{3}\right)$ $\delta 152.0 \mathrm{C}_{1}, 148.7 \mathrm{C}_{3}, 119.7 \mathrm{C}_{4}, 126.9 \mathrm{C}_{5}, 136.0 \mathrm{C}_{6}$, $162.1 \quad \mathbf{C}=\mathbf{0}, 126.9 \mathrm{C}_{7}, 51.4 \mathrm{C}_{10}, 46.4 \mathrm{C}_{11}, 162.2$ $\mathrm{C}_{12}, 148.7 \mathrm{C}_{16}, 101.0 \mathrm{C}_{17}, 127.1 \mathrm{C}_{18}, 136.0 \mathrm{C}_{23}, 67.6$ $\mathrm{C}_{24}$. MS: $[\mathrm{m} / \mathrm{z}] 512(\mathrm{M}+1)$ Anal. Calcd./found for $\mathrm{C}_{25} \mathrm{H}_{24} \mathrm{ClN}_{4} \mathrm{O}_{7}$ : C, 62.76/62.81; H, 7.37/7.53; Cl, 6.18/6.29; N, 8.51/8.58, O; 16.20/16.28.

\section{Antimicrobial activity}

The in vitro antimicrobial activity of compounds $\mathbf{1}$, $\mathbf{3}, \mathbf{4 a}$ and $\mathbf{5 b}$ was performed using the disk diffusion method. Streptomycin for bacteria and fluconazol for fungal were used as standard drugs. The compounds $\mathbf{1}$, $\mathbf{3}, \mathbf{4 a}$ and $\mathbf{5 b}$ were tested for their antibacterial and antifungal activities by disk-diffusion method using nutrient broth medium [contained $(\mathrm{g} / \mathrm{l})$ : beef extract $3 \mathrm{~g}$; peptone $5 \mathrm{~g} ; \mathrm{pH}$ 7.0] for bacteria and potato dextrose broth medium [contained (g/l): beef extract $3 \mathrm{~g}$; peptone $5 \mathrm{~g} ; \mathrm{pH} 7.0]$ for fungi .The Gram-positive bacteria and Gram-negative bacteria utilized in this study consisted of Escherichia coli, and Bacillus subtilis for bacterial species and Aspergillus niger and Fusarium oxysporum for the fungal species. In the disk-diffusion method, sterile paper disks $(0.5 \mathrm{~mm})$ impregnated with compound dissolved in dimethylsulphoxide (DMSO) at concentration 100, 200 and $400 \mu \mathrm{g} / \mathrm{ml}$ were used. Then, the paper disks impregnated with the solution of the tested compounds were placed on the surface of the media inoculated with the microorganism. The plates were incubated at $35^{\circ} \mathrm{C}$ for $24 \mathrm{~h}$. After incubation, the growth inhibition zones and activity were checked. The outcome of this study is presented in table 1 .

\section{In vitro cytotoxicity assay}

MCF7 (hormone-dependant breast carcinoma cell line), HT29 (colon carcinoma cell line were purchased from the Microbial Type Culture Collection (MTCC), Chandigarh. The viability of the cells was checked before and after treatment by the trypan blue exclusion dye method. Frozen cell stocks were stored in liquid nitrogen $\left(-196^{\circ} \mathrm{C}\right)$ prior to use. The MCF7 and
HT29 cells were maintained in RPMI 1640 medium (Sigma), supplemented with $10 \%$ fetal bovine serum (FBS, MP Biomedicals, Mumbai), $100 \mu \mathrm{g} / \mathrm{ml}$ Ampicillin (CDH, New Delhi) and $50 \mu \mathrm{g} / \mathrm{ml}$ of fluconazole (MP Biomedicals, Mumbai). The cells were cultured in a $5 \% \mathrm{CO}_{2}$ incubator (Accurate) kept at $37^{\circ} \mathrm{C}$ in a humidified atmosphere. The culture was subcultured every two to three days as needed and routinely checked under an inverted microscope (IMT-2 Olympus, Japan) for any contamination.

\subsection{In vitro neutral red cytotoxicity assay}

The neutral red cytotoxicity assay was followed as previously described. ${ }^{36}$ Briefly, cells were detached from the tissue culture flask with $0.25 \%$ trypsin-ethylene diamine tetra acetic acid (EDTA) solution and phosphate buffered saline (PBS) solution and washed in culture medium. The cell pellet was obtained by centrifugation at $1000 \mathrm{rpm}$ for $5 \mathrm{~min}$. The density of the viable cells was counted by $0.4 \%$ of tryphan blue exclusion in a haemocytometer (Rohem). The cells $(1 \times 104 /$ well $)$ were then plated in a 96-well microtiter plate (Biotron Healthcare) in a volume of $190 \mu \mathrm{l}$. The plate was incubated in a $\mathrm{CO}_{2}$ incubator at $37^{\circ} \mathrm{C}$ for $24 \mathrm{~h}$ to allow the cells to adhere and achieve 60 $70 \%$ confluence at the time of the addition of the test agents (that is, test extracts and positive control). After $24 \mathrm{~h}$ of incubation, the cells were treated with different concentrations $(1,10,50$ and $100 \mu \mathrm{g} / \mathrm{ml})$ of each test agents in three replicate tests. The plates were incubated for $72 \mathrm{~h}$ at $37^{\circ} \mathrm{C}$ in a $5 \% \mathrm{CO}_{2}$ incubator. DMSO was used to dilute the test agents and the final concentration of DMSO in test wells and control wells used was not in excess of $1 \%(\mathrm{v} / \mathrm{v})$. No effect due to the DMSO was observed 5FU (MP Biomedicals, Mumbai) was used as the positive control. The well containing untreated cells is the negative control. At the end of the incubation period, the media was replaced with medium containing $50 \mu \mathrm{g} / \mathrm{ml}$ neutral red. The plates were incubated for another $3 \mathrm{~h}$ to allow for uptake of the vital dye into the lysosomes of viable and uninjured cells. After the incubation period, the media was removed and cells were washed with the neutral red washing solution. The dye was eluted from the cells by adding $200 \mu \mathrm{l}$ of neutral red resorb solution and further incubated for $30 \mathrm{~min}$ at room temperature with rapid agitation on a microtiter plate shaker (Biotron Healthcare). Dye absorbance was measured at $540 \mathrm{~nm}$ using ELISA reader (Biotron Healthcare). Three replicate plates were used to determine the cytotoxicity of each test agent. The cytotoxic effect of each 


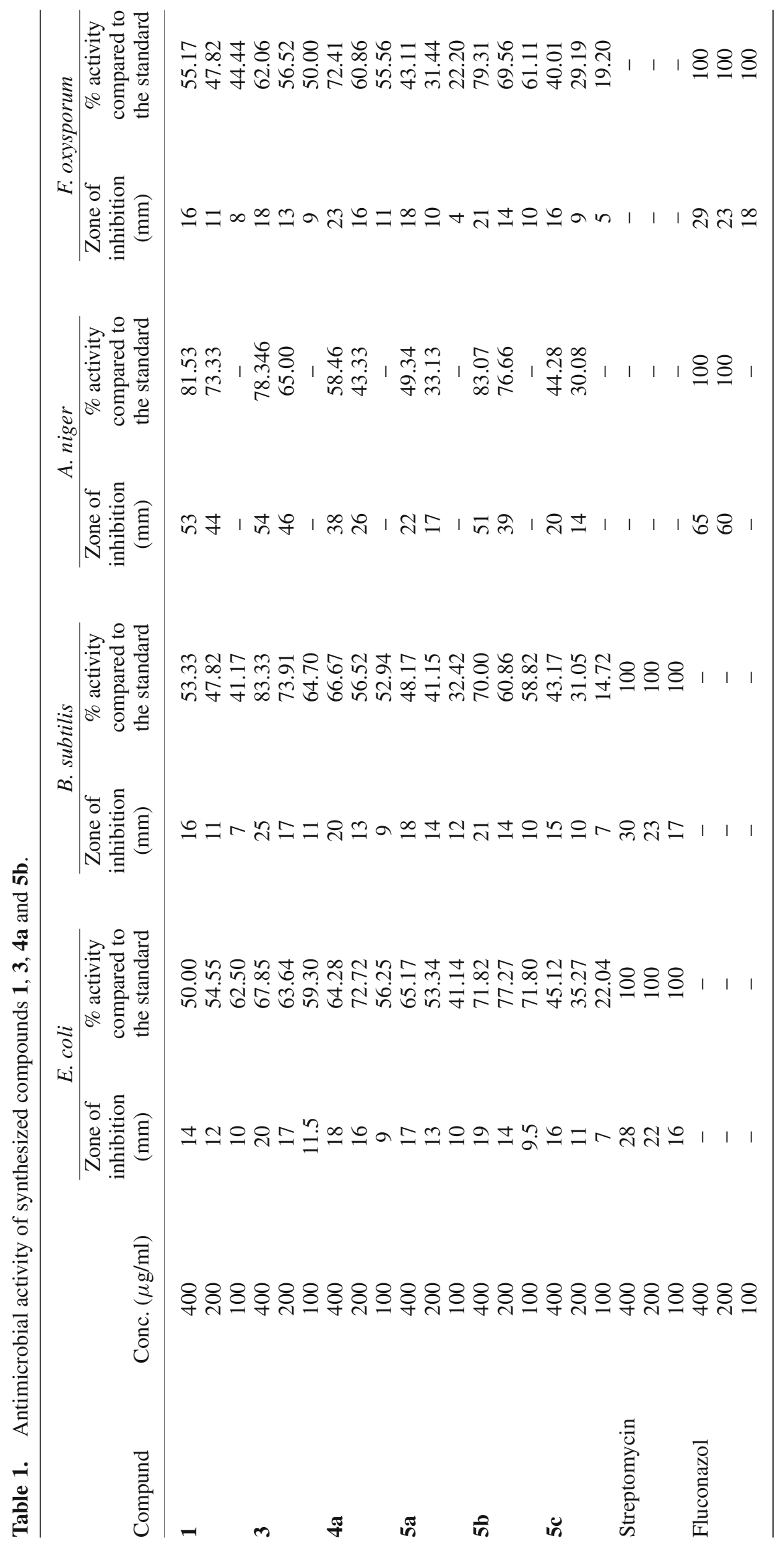


test agent was evaluated based on percentage inhibition values. The percentage of inhibition (\%) was calculated according to the following formula:

$$
\begin{aligned}
& \text { Percentage of inhibition }(\%) \\
& =\frac{\text { OD control }- \text { OD sample } \times 100 \%}{\text { OD control }} .
\end{aligned}
$$

The average of three replicates was then obtained. Cytotoxicity of each test agent is expressed as $\mathrm{IC}_{50}$ value. The $\mathrm{IC}_{50}$ value is the concentration of test agents that cause 50\% inhibition or cell death, averaged from the three experiments, and was obtained by plotting the percentage inhibition versus concentration of test agents. ${ }^{37}$

\section{Results and discussion}

A new synthetic method for the preparation of oxazolidinone has been developed and obtained the desired oxazolidinone derivatives in $54-80 \%$ yields. All the nine compounds were prepared by refluxing in the presence of solvent (dry ethanol, acetone and benzene). The obtained compounds are stable in the solid state. Characteristic IR bands provide significant indications for the formation of oxazolidinone derivatives. IR spectra of all the compounds showed 1500$1578 \mathrm{~cm}^{-1}$ (NH str.), $1735-1770 \mathrm{~cm}^{-1}(\mathrm{C}=\mathrm{O}$ str.), $1600-1475 \mathrm{~cm}^{-1}(\mathrm{C}=\mathrm{C}$ str. $)$, which confirmed the formation of oxazolidinone derivatives. Structure of oxazolidinone derivatives were further confirmed by ${ }^{1} \mathrm{H}-$ NMR spectra, which proved as a diagnostic tool for the positional elucidation of the proton. Assignments of the signals are based on chemical shift and intensity pattern. The ${ }^{1} \mathrm{H}-\mathrm{NMR}$ spectra showed multiplates in the region 1.5-2.0 ppm for $\left(\mathrm{CH}_{2}\right)$ and doublets in the region $8.14-7.3 \mathrm{ppm}$ for aromatic proton in all spectra, respectively. Characteristic peaks were observed in the mass spectra of all compounds which followed the similar fragmentation pattern. The spectra of compounds showed molecular ion peak $\left(\mathrm{M}^{+}\right)$at $\mathrm{m} / \mathrm{z}$ which confirmed the molecular weight of the oxazolidinone derivatives.

The antibacterial activity was evaluated against two pathogenic strains (E. coli and B. subtilis). The zone of inhibition and activity index were determined by comparison with the standard drug streptomycin. The outcome of this study is presented in table 1 . The antibacterial screening against $E$. coli showed that amongst the compounds $\mathbf{1}, \mathbf{3}, \mathbf{4 a}$ and $\mathbf{5 b}$ the compound $\mathbf{5 b}$ displayed highest activity. The compound $\mathbf{1}$ showed minimum activity amongst all the compounds. The remaining compounds $\mathbf{4 a}$ and $\mathbf{3}$ showed only moderate activity.
Table 2. In vitro cytotoxicity on MCF7and HT29 cells of compounds $\mathbf{5 a - c}$.

\begin{tabular}{lcc}
\hline & $\begin{array}{c}\text { Cytotoxicity } \\
\text { on MCF7 }\end{array}$ & $\begin{array}{c}\text { Cytotoxicity } \\
\text { on HT29 }\end{array}$ \\
\cline { 2 - 3 } & $\mathrm{IC}_{50}(\mu \mathrm{g} / \mathrm{mL})$ & $\mathrm{IC}_{50}(\mu \mathrm{g} / \mathrm{mL})$ \\
\hline 5-Fluorouracil & $1.3 \pm 0.76$ & $5.6 \pm 1.40$ \\
Chloroquinoline & $49.4 \pm 0.56$ & $56.6 \pm 3.09$ \\
5a & $16.1 \pm 3.40$ & $32.4 \pm 5.03$ \\
5b & $46.0 \pm 4.17$ & $54.0 \pm 3.19^{*}$ \\
5c & $38.2 \pm 3.08$ & $49.0 \pm 2.30$ \\
\hline
\end{tabular}

The values expressed are mean \pm standard deviation of triplicate measurements

*Not significant

Contrary to this observation, compound $\mathbf{3}$ showed highest activity amongst all the compounds screened for this activity against $B$. subtilis.

Similarly, the antifungal activity was evaluated against two pathogenic strains (A. niger and $F$. oxysporum). The zone of inhibition and activity index were determined by comparison with the standard drug fluconazol. The outcome of this study is presented in table 1. The antifungal screening against $A$. niger showed that amongst the compounds $\mathbf{1}, \mathbf{3}, \mathbf{4 a}$ and $\mathbf{5 b}$, the compound $\mathbf{5 b}$ displayed highest activity. The compound 4a showed minimum activity amongst the entire compound. The remaining compounds $\mathbf{1}$ and $\mathbf{3}$ showed only moderate activity. Contrary to this observation, compound $\mathbf{5 b}$ showed highest activity amongst all the compounds screened for this activity against $F$. oxysporum.

All the compounds 5a-c were tested for their biological activities towards MCF7and HT29 cells lines and the results are shown in table $2 . \mathrm{IC}_{50}$ value lower than $50 \mu \mathrm{g} / \mathrm{mL}$ was considered as active for cytotoxicity on MCF7 and HT29 cells. 5-Fluorouracil was used as positive reference compound. The MCF7 cell line was found to be very susceptible towards compound $\mathbf{5 a}$ with $\mathrm{IC}_{50}$ values of $16 \mu \mathrm{g} / \mathrm{ml}$ while medium inhibitory activities were observed for compounds $\mathbf{5 c}$ with $\mathrm{IC}_{50}$ values of 38 and weak activity was observed for compound $\mathbf{5 b}$ with an $\mathrm{IC}_{50}$ value of $46 \mu \mathrm{g} / \mathrm{ml}$, respectively. Similarly, the HT29 cell line was found to be moderately susceptible towards compounds $\mathbf{5 a}$ and $\mathbf{5 c}$ with $\mathrm{IC}_{50}$ values of 32 and $49 \mu \mathrm{g} / \mathrm{ml}$, respectively while compound $\mathbf{5 b}$ had no activities $\left(\mathrm{IC}_{50}>54.0 \mu \mathrm{g} / \mathrm{ml}\right)$ against the cell line.

\section{Conclusion}

In conclusion, novel oxazolidinone analogues of chloro quinoline 5(a-c) displaying potential antibacterial and antifungal activities were synthesized. The results 
showed that the addition of the oxazolidinone ring on the quinoline molecule framework increased the antibacterial activity. Among the four compounds, oxazolidinone derivative showed better antibacterial and antifungal activity than the respective drug streptomycin and fuconazol. The compound 5a was found to be most potent inhibitor of both the cancer cell lines i.e., MCF7and HT29 cells lines.

The importance of such work lies in the possibility that the new synthesized compound might be a more efficacious drug against various bacterial species for which a thorough investigation regarding the structureactivity relationship, mechanism of action and toxicity in their biological effects which could be helpful in designing more potent antibacterial and antifungal agents for therapeutic use.

\section{Supplementary information}

The electronic supporting information can be seen in www.ias.ac.in/chemsci.

\section{Acknowledgements}

Authors are thankful to the Department of Science and Technology (DST), New Delhi (India) for providing financial assistance to Banasthali Centre for Education and Research in Basic Sciences under their CURIE (Consolidation of University Research for Innovation and Excellence in Women University) programme. Authors thank the Director, Central Drug Research Institute (CDRI), Lucknow, India and Dr. Anees A Siddiqui, Jamiya Hamdard University, Delhi, India (for providing the spectral data of the compounds). Authors are also thankful to the Head, Department of Bioscience and Biotechnology, Banasthali University for carrying out antimicrobial screening and to Pinnacle Biomedical Research Institute (PBRI), Bhopal for carrying out cytotoxicity assay).

\section{References}

1. Raether W and Hanel H 2003 Parasitol. Res. 1(2) 19

2. Fluit A C, Schmitz F J, Verhoef J and Milatovic D 2002 J. Antimicrob. Chemother. 50(2) 271

3. Robert L, Goldenberg M D, John C, Hauth M D and William W Andrews 2000 N. Engl. J. Med. 342(5) 1500

4. Leach L K, Brickner S J, Noe C M and Miller P F 2011 Ann. N Y Acad. Sci. 1222(3) 49

5. Swaney S M, Aoki H, Ganoza M C and Shinabarger D L 1998 Antimicrob. Agents Chemother. 42(12) 3251

6. Yonath A 2005 Annu. Rev. Biochem. 74(7) 649
7. Lin A H, Murray R W, Vidmar T J and Marotti K R 1997 Antimicrob. Agents Chemother. 41(10) 2127

8. Xiong L, Kloss P, Douthwaite S, Andersen N M, Swaney S, Shinabarger D L and Mankin A S 2000 J. Bacteriol. 182(10) 5325

9. Eustice D C, Feldman P A and Slee A M 1988 Biochem. Biophys. Res. Commun. 150(10) 965

10. Burghardt H, Schimz K L and Muller M 1998 FEBS Lett. 425(3) 40

11. Murray R W, Schaadt R D, Zurenko G E and Marotti K R 1998 Antimicrob. Agents Chemother. 42(4) 947

12. Slee A M, Wuonola M A, McRipley R J, Zajac I, Zawada M J, Bartholomew P T, Gregory W A and Forbes M 1987 Antimicrob. Agents Chemother. 31(11) 1791

13. Ford C W, Hamel J C, Stapert D, Moerman J K, Hutchinson D K, Barbachyn M R and Zurenko G E 1997 Trends Microbiol. 5(5) 196

14. Fugitt R B and Martinelli L C 1973 J. Pharma. Sci. 62(6) 1013

15. Venkata Rami Reddy Macherla, Benjamin Nicholson and Kin Sing Lam 2008 United State Patent Application 20080221182 Kind Code-A

16. Venkata Rami Reddy Macherla, Benjamin Nicholson and Kin Sing Lam 2008 United State Patent Application 20080221183 Kind Code-A

17. Sternberg J A, Geffken D, Adams Jr J B, Pöstages R, Strenberg C G, Cambbell C L and Moberg W K 2001 Pest Manag. Sci. 57(2) 143

18. Edafiogho I O, A-phillips O, Edet E, Samuel S and Rethish B 2009 Eur. J. Med. Chem. 44(3) 679

19. Walter K, Gerald K, Huth A, Froehlich W and Laurent H 1999 United State Patent Application 5998453

20. Willam J W, Grover C H, Roy T C, Turnbull L B and John P D 1973 J. Med. Chem. 16(10) 1129

21. Cynamon M H, Klemens S P, Sharpe C A and Case S 1999 Antimicrob. Agents Chemother. 43(5) 1189

22. Vera-Carbrera L, Gonazalez E, Velazquez-moreno A M, Choi S H and Molina-Torres C 2006 Antimicrob. Agents Chemother. 50(3) 3170

23. Kiran G S, Kumar R, Ali A, Madhavi N L, Anjum S G, Cao H, Nathans R S, Schiffer C A and Rana T M 2007 J. Med. Chem. 50(8) 4316

24. Ali A, Kiran G S, Reddy K, Cao H, Anjum S G, Madhavi L, Schiffer C A and Rana T R 2006 J. Med. Chem. 49(12) 7342

25. Bhatt J J, Trivedi P B, Undavia N K and Desai N C 1994 Indian J Chem. 33B(2) 189

26. Momose $Y$, Maekawa $T$, Yamano $T$, Kawada M, Odaka H, Ikeda H and Sohda T 2002 J. Med. Chem. 45(7) 1518

27. Muller M and Schimz L K 1999 Cell. Mol. Life Sci. 56(2) 280

28. Biavalli M W, Veira P C and De-silva M F 2002 J. Brazilian Chem. Soc. 13(1) 66

29. Robert M, Jampilek J, Kralova K, Richmann D R, Kaliwoshki D and Polonski J 2007 J. Biorg. Med. Chem. 3(1) 1280

30. Abele E, Abele A, Rubina K and Lukinesa E 2005 Chem. Hetero. Comp. 41137

31. Robert M, Jampilek J, Kralova K, Richmann D R, Kaliwoshki D and Polonski J 2007 J. Med. Chem. 45308 
32. Abrahim M A, Abdu E A A and Bakhite E A 1991 Phosphorus, Sulfur Silicon Related Element 57(3-4) 293

33. Feng X U, Ding Q, Yang K and Jing W G 2006 Chinese Chem. Lett. 17(2) 187

34. Gramik V G, Zhidkava A M, Kiselev S S, Ghohkov R G, Polezhaeva A J and Moshkovshi M D 1978 Pharma. Chem. 12(7) 881
35. Nazullaev S S, Bessanava I A and Akhmedkhodzhaeva K S 2001 Chem. Natural Comp. 37551

36. Nurestri A M, Sim K S, Norhanom A W, Hashim Y 2009 Molecules 14(5) 1713

37. Geran R I, Greenberg N H, McDonald M M, Schumacher A M, Abbott B J 1972 Cancer Chemother. Rep. 317 